\title{
Role of biodeposition by Mytilus edulis in the circulation of matter and nutrients in a Baltic coastal ecosystem
}

\author{
Nils Kautsky ${ }^{1} \&$ Sverker Evans $^{2}$ \\ ${ }^{1}$ Askö Laboratory, Institute of Marine Ecology and Department of Zoology, University of Stockholm, S-10691 Stockholm, \\ Sweden \\ ${ }^{2}$ Department of Zoology, Uppsala University, Box 561, S-751 22 Uppsala, Sweden
}

\begin{abstract}
Biodeposit production of Mytilus edulis was studied in situ over an annual cycle in the northern Baltic proper. Faeces and pseudofaeces were collected in traps covered by a layer of mussels and placed on the bottom at $5 \mathrm{~m}$ depth. The summed deposition due to sedimentation and biodeposition was compared with deposition in mussel-free control traps on the bottom and suspended in the water column. Both quantity and quality of deposited matter increased through biodeposition. Relative contribution of material from $M$. edulis was highest in summer, whereas both sedimentation and biodeposition peaked in autumn. Annual biodeposition by $M$. edulis was $1.76 \mathrm{~g}$ dry weight, $0.33 \mathrm{~g}$ ashfree dry weight, $0.13 \mathrm{~g}$ carbon, $1.7 \times 10^{-3} \mathrm{~g}$ nitrogen and $2.6 \times 10^{-4} \mathrm{~g}$ phosphorus per $\mathrm{g}$ mussel (dry weight including shells). During the productive season from April to September the organic content of biodeposits was higher than that of naturally sedimenting material (30.4 vs $24.8 \%$ ), despite having passed the mussels' alimentary tracts. Nitrogen content of biodeposited material was also higher than that in control traps (1.68 vs $1.20 \%$ of dry weight), while phosphorus content was the same $(0.19 \%)$ in both. The higher contents of carbon and nitrogen in biodeposits may be explained by the fact that the mussels to a large extent remove and initiate the sedimentation of small particles of high organic content which would otherwise stay in suspension. We argue that $M$. edulis occupies an important role as a connecting link between pelagic and benthic ecosystems by increasing total annual deposition of $C, N$ and $\mathrm{P}$ by $10 \%$ and by circulating and regenerating 12 and $22 \%$, respectively, of the annual $\mathrm{N}$ and $\mathrm{P}$ demands for pelagic primary production in the area.
\end{abstract}

\section{INTRODUCTION}

Mussels are known as efficient filter feeders that may reach high biomasses in favourable areas where predation and competition are low as in e.g. mussel cultures (Kaspar et al. 1985), some shallow or estuarine areas, such as salt marshes (e.g. Kuenzler 1961a, b), the Danish Limfjord (e.g. Theisen 1968), the Dutch Wadden Sea (e. g. Verwey 1952) or the brackish Baltic Sea (Jansson \& Kautsky 1977, Kautsky 1981a). At high densities they are able to deplete the water mass of plankton, both in the benthic boundary layer (Wildish \& Kristmanson 1984, Frechette \& Bourget 1985) as well as in entire coastal embayments (Cloern 1982), possibly leading to 'eutrophication control' (Officer et al. 1982) or nutrient depletion in mussel culture areas (Kaspar et al. 1985). This high consumption of particulate suspended matter is partly diverted to metabolism, growth and production of offspring. However, a large part of the ingested particulate material is also voided as faeces or excreted as dissolved nutrients. Since high biomasses of mussels are generally due to low predation mortality, and mussels have the ability to respire away significant parts of their biomass before natural death (Kautsky 1981a), gametes are often found to be the largest component of mussel production to enter the food webs in high biomass areas (Kautsky 1981a, b, 1982b, Jordan \& Valiela 1982). Accordingly, Kuenzler (1961b) and Kautsky (1981b) suggested that mussels are more important as agents of sedimentation and nutrient cycling than as agents of energy flow.

Biodeposits from benthic suspension-feeders may contribute significantly to the total suspended load in estuarine and coastal environments. Verwey (1952), Haven \& Morales-Alamo (1966, 1972), Kraeuter (1976) and Smaal et al. (1986) have emphasized the importance of mussels in the removal and depositon of suspended particulate matter. The magnitude of removal 
may be sufficient to influence the sedimentary process, and Biggs \& Howell (1984) even concluded that biologically mediated sedimentation processes have the capability to overwhelm all others in the deposition of fine sediments in estuaries. These deposits may represent a significant proportion of the energy potentially available to consumer invertebrates as a food resource (Newell 1965, Johannes \& Satomi 1966, Frankenberg \& Smith 1967, Frankenberg et al. 1967, Tenore et al. 1973, Vahl 1980, Kautsky 1981b, Newell et al. 1982 Stuart et al. 1982).

Newell et al. (1982) calculated that one third of the annual production of particulate matter in a kelp bed area was faecal matter originating from benthic animals. After bacterial enrichment this was to a large extent reingested and Newell et al. (1982) concluded that such a mussel 'faecal loop' plays a significant role in the circulation of nutrient and matter in the kelp community.

In the Baltic Sea, the blue mussel Mytilus edulis totally dominates benthic animal biomass due to the exclusion of its major predators which cannot survive the low salinity. As a consequence, heavy intraspecific competition occurs and the Baltic mussel populations mostly consist of strongly space- and food-limited individuals (Kautsky 1981a, 1982a, b). In the Bothnian Bay, where salinities are too low even for mussels, Elmgren (1984) showed that energy flows differ markedly from those in more marine areas probably due to the lack of the filter feeder function.

Much work on particle retention by filter feeders has focused on the role of bivalves in influencing the soft bottom environment of particulate matter (e.g. Black 1982). However, there is a paucity of data on biodeposit production by bivalve molluscs under natural conditions. Our present understanding of the effects of the feeding activity by mussels on the deposition of particulate material has been derived mainly from laboratory experiments (Kuenzler 1961a, b, Haven \& Morales-Alamo 1966, Tenore \& Dunstan 1973a, b, Tenore et al. 1973, Kraeuter 1976. Tsuchiya 1980), and we are aware of no studies of biodeposit production by bivalves under natural conditions.

In this study production of faeces by Mytilus edulis in the Baltic was measured in situ and compared with natural sedimentation. We also evaluate the role of blue mussels in the circulation of nitrogen and phosphorus in a coastal area and show its importance as a connecting link between the pelagic and benthic ecosystems

\section{MATERIAL AND METHODS}

Seasonal biodeposition by Mytilus edulis was recorded in 1980 and 1981 at $5 \mathrm{~m}$ depth at Vrångskär, an exposed rocky bottom close to the Askö Laboratory in the northern Baltic $\left(58^{\circ} 49.2^{\prime} \mathrm{N}, 17^{\circ} 37.6^{\prime} \mathrm{E}\right)$. Eight PVC cylinders were tied to a rack which was lowered to the bottom by divers. The tops of the cylinders were covered by 2 nets ( $5 \mathrm{~mm}$ mesh), $20 \mathrm{~mm}$ apart (Fig. 1).

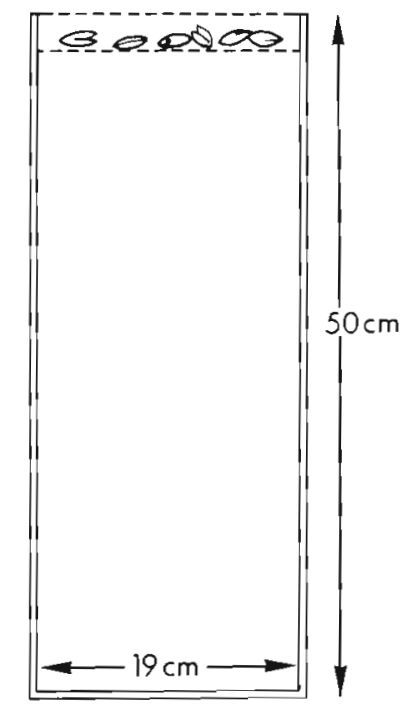

Fig. 1. Sediment trap for in situ determination of biodeposition by Mytilus edulis. The mussels are resting on a $5 \mathrm{~mm}$ mesh and are covered by a mesh of similar size

Mussels were placed between the nets in 5 of the cylinders so that about $1 / 3$ to $1 / 4$ of the net area was covered by a layer of mussels. Mussel biomasses within the cylinders ranged between 535 and $1693 \mathrm{~g} \mathrm{~m}^{-2}$, which can be compared with the average mussel biomass of $620 \mathrm{~g} \mathrm{~m}^{-2}$ (dry weight including shells) or $91 \mathrm{~g}$ $\mathrm{m}^{-2}$ (dry flesh wt.) found on the surrounding bottom (Kautsky 1981b). Naturally sedimenting material was collected in all the cylinders, while in those containing mussels, the latters' faeces were also collected. Biodeposition was calculated as the amount of material collected in each mussel cylinder minus the average sedimentation obtained in the 3 control traps.

After 9 to $28 \mathrm{~d}$ the cylinders were retrieved by divers and taken to the laboratory where the supernatant water in the cylinders was siphoned off and excess water in the remaining sediment was removed by centrifugation. The sedimented material was then dried at $60^{\circ} \mathrm{C}$ and analysed. Dry weights were corrected for salt content, and ash-free dry weights of the sediment were determined after ashing at $500^{\circ} \mathrm{C}$ for $5 \mathrm{~h}$. Total organic carbon was determined by combustion at $950^{\circ} \mathrm{C}$ with a Beckman Analyser Model 915 B. Total organic nitrogen was analysed as $\mathrm{NH}_{4}-\mathrm{N}$ after a modified Kjeldahl combustion. Total organic phosphorus in the sediment was analysed as $\mathrm{PO}_{4}-\mathrm{P}$ after acid treatment according to Ahlgren (1976). All analyses were run in duplicate. If 
the duplicates deviated more than $5 \%$ from each other the samples were re-analysed. The average difference (means \pm range) between duplicates was $2.4 \pm 1.9 \%$ for $C, 1.4 \pm 0.9 \%$ for $N$ and $1.9 \pm 1.8 \%$ for $P$.

\section{RESULTS}

\section{Sedimentation and biodeposition rates}

The annual pattern of biodeposition by Mytilus edulis and the natural sedimentation, together with phytoplankton biomass and water temperature, are given in Fig. 2. Both sedimentation and biodeposition were generally low in spring, increasing during summer and reaching a maximum during the stormy autumn period. Both sedimentation and biodeposition peaked during October to December with 62 and $52 \%$ of their annual load, respectively, being deposited then. Thus, $60 \%$ of the total annual load settling onto the bottom occurred within this 3 mo period. Biodeposition contributed $24 \%$ to the total annual sediment load.

Average natural sedimentation ranged from 1 to $37 \mathrm{~g}$ dry wt. $\mathrm{m}^{-2} \mathrm{~d}^{-1}$, while biodeposition varied from 1 to $16 \mathrm{mg} \mathrm{d}^{-1}$ per g mussel (dry wt. incl. shells) (Table 1, Fig. 2). The corresponding values for ashfree dry wt. were 0.2 to 3.3 and 0.2 to $1.2 \mathrm{~g} \mathrm{~m}^{-2} \mathrm{~d}^{-1}$ for sedimentation and biodeposition, respectively.

The relative contribution of biodeposition to sedimentation is shown in Fig. 3 using the average mussel biomass of $620 \mathrm{~g} \mathrm{~m}^{-2}$ (dry wt. incl. shells) for the site given by Kautsky (1981b). The biodeposition/ sedimentation ratio varied seasonally, being low during September to April and generally high from May to August. Biodeposition exceeded sedimentation in May-June and in August (Fig. 3). The peak in May occurred during spawning of the mussels and was fully explained if about $1 / 10$ of the spawn produced by the mussels on top of the cylinders was assumed to settle in the traps (calculated from Kautsky 1982a). The peak in August coincided with a period of low sedimentation, and there is a general tendency for the relative importance of biodeposition to increase when natural sedimentation is low. The same annual pattern is seen if ashfree dry weights are compared but the contribution from mussels is then some 10 to $20 \%$ higher.

\section{Seasonal variation in organic content, carbon, nitrogen and phosphorus}

Ashfree dry wt., total $\mathrm{N}$, total $\mathrm{P}$ and organic $\mathrm{C}$ all showed a decreasing trend during the year (Fig. 4). Generally, the content of organic matter, carbon and nitrogen was higher in the biodeposits than in the naturally sedimented material. The greatest differences were found during the productive season from April to the end of September, when the activity of the

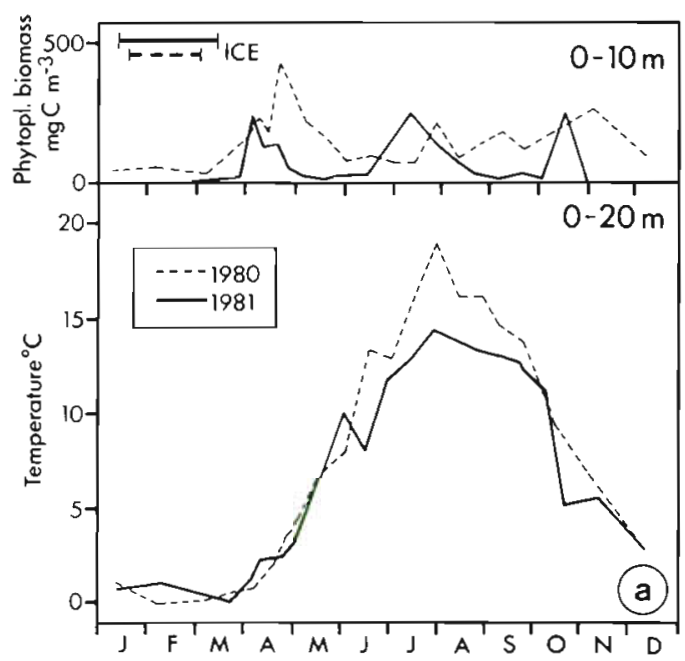

Fig. 2. (a) Annual variation in phytoplankton biomass and water temperature in the research area (from Larsson \& Johansson 1984). (b) Biodeposition by Mytilus edulis and natural sedimentation expressed as $g$ dry weight and $g$ ashfree dry weight $\mathrm{m}^{-2} \mathrm{~d}^{-1} \pm \mathrm{SE}$ of means at Vrångskär, $5 \mathrm{~m}$ depth

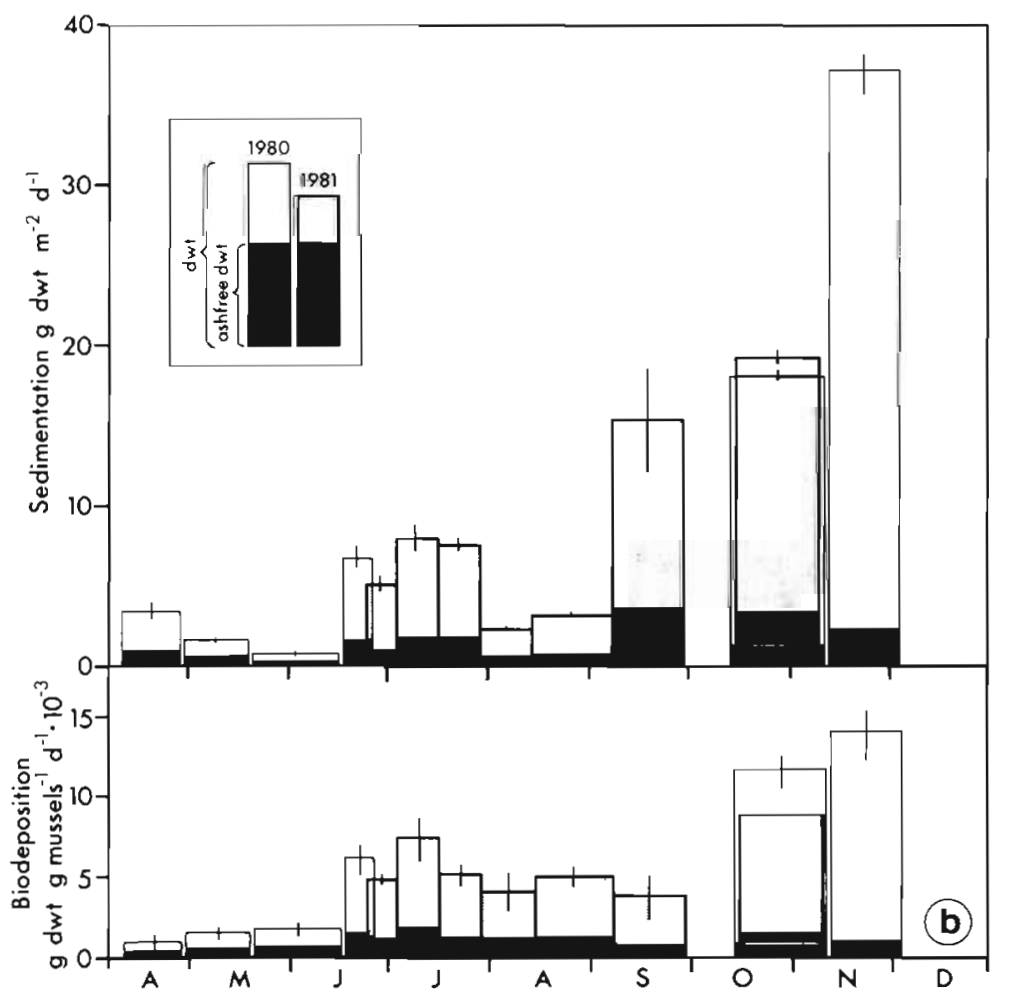


Table 1. Sedimentation in control traps, and biodeposition by Mytilus edulis at $5 \mathrm{~m}$ depth ( \pm SE of means)

\begin{tabular}{|c|c|c|c|c|c|c|c|c|}
\hline \multirow[t]{2}{*}{ Period } & \multirow[t]{2}{*}{$\begin{array}{c}\text { Exposure } \\
\text { time (d) }\end{array}$} & \multicolumn{2}{|c|}{$\begin{array}{l}\text { Sedimentation } \\
\left(\mathrm{g} \mathrm{m}^{-2} \mathrm{~d}^{-1}\right)\end{array}$} & \multicolumn{2}{|c|}{$\begin{array}{l}\text { Biodeposition } \\
\left(\mathrm{g} \mathrm{m}^{-2} \mathrm{~d}^{-1}\right)\end{array}$} & \multirow{2}{*}{$\begin{array}{c}\text { Biomass of } \\
\text { M. edulis }(\mathrm{g}) \\
\text { Dry wt }\end{array}$} & \multicolumn{2}{|c|}{$\begin{array}{c}\text { Biodeposition as } \\
\% \text { of sedimentation. }\end{array}$} \\
\hline & & Dry wt & Ashfree dry wt & Dry wt & Ashfree dry wt & & Dry wt & Ashfree dry wt \\
\hline \multicolumn{9}{|l|}{1980} \\
\hline $10 \mathrm{Apr}-28 \mathrm{Apr}$ & 18 & $3.37 \pm 0.47$ & $0.86 \pm 0.22$ & $0.52 \pm 0.50$ & $0.24 \pm 0.23$ & $27.7 \pm 0.4$ & 16 & 28 \\
\hline 29 Apr-19 Мay & 20 & $1.64 \pm 0.12$ & $0.57 \pm 0.04$ & $0.83 \pm 0.25$ & $0.28 \pm 0.08$ & $28.5 \pm 15.6$ & 51 & 49 \\
\hline 20 May-16 Jun & 27 & $0.69 \pm 0.02$ & $0.22 \pm 0.01$ & $0.97 \pm 0.33$ & $0.38 \pm 0.13$ & $26.5 \pm 14.4$ & 141 & 173 \\
\hline 17 Jun-26 Jun & 9 & $6.67 \pm 0.70$ & $1.63 \pm 0.17$ & $3.91 \pm 1.42$ & $1.04 \pm 0.38$ & $24.6 \pm 12.9$ & 58 & 64 \\
\hline 14 Oct-11 Nov & 28 & $18.14 \pm 0.32$ & $1.27 \pm 0.02$ & $9.14 \pm 3.62$ & $0.83 \pm 0.33$ & $15.8 \pm 10.0$ & 50 & 65 \\
\hline 12 Nov- $3 \mathrm{Dec}$ & 21 & $36.95 \pm 1.56$ & $2.76 \pm 0.12$ & $9.76 \pm 4.52$ & $0.69 \pm 0.32$ & $15.1 \pm 9.4$ & 26 & 25 \\
\hline \multicolumn{9}{|l|}{1981} \\
\hline 24 Jun- 3 Jul & 9 & $5.14 \pm 0.52$ & $1.05 \pm 0.11$ & $3.12 \pm 1.41$ & $0.75 \pm 0.34$ & $29.6 \pm 13.0$ & 61 & 71 \\
\hline $3 \mathrm{Jul}-16 \mathrm{Jul}$ & 13 & $7.94 \pm 0.85$ & $1.73 \pm 0.18$ & $4.67 \pm 1.78$ & $1.24 \pm 0.47$ & $31.6 \pm 13.5$ & 59 & 71 \\
\hline 16 Jul-29 Jul & 13 & $7.55 \pm 0.36$ & $1.65 \pm 0.08$ & $3.08 \pm 1.67$ & $0.84 \pm 0.45$ & $33.0 \pm 15.1$ & 41 & 51 \\
\hline $29 \mathrm{Jul}-14 \mathrm{Aug}$ & 16 & $2.37 \pm 0.20$ & $0.55 \pm 0.05$ & $2.81 \pm 0.86$ & $0.77 \pm 0.24$ & $34.7 \pm 14.0$ & 119 & 140 \\
\hline $14 \mathrm{Aug}-7 \mathrm{Sep}$ & 26 & $3.22 \pm 0.23$ & $0.72 \pm 0.05$ & $3.25 \pm 0.89$ & $0.84 \pm 0.23$ & $38.1 \pm 15.2$ & 101 & 117 \\
\hline $7 \mathrm{Sep}-29 \mathrm{Sep}$ & 22 & $15.29 \pm 3.30$ & $3.28 \pm 0.71$ & $2.29 \pm 1.38$ & $0.59 \pm 0.35$ & $41.4 \pm 16.0$ & 15 & 18 \\
\hline 15 Oct-10 Nov & 26 & $19.25 \pm 0.46$ & $3.35 \pm 0.08$ & $4.79 \pm 0.50$ & $0.69 \pm 0.07$ & $47.9 \pm 7.1$ & 25 & 20 \\
\hline
\end{tabular}

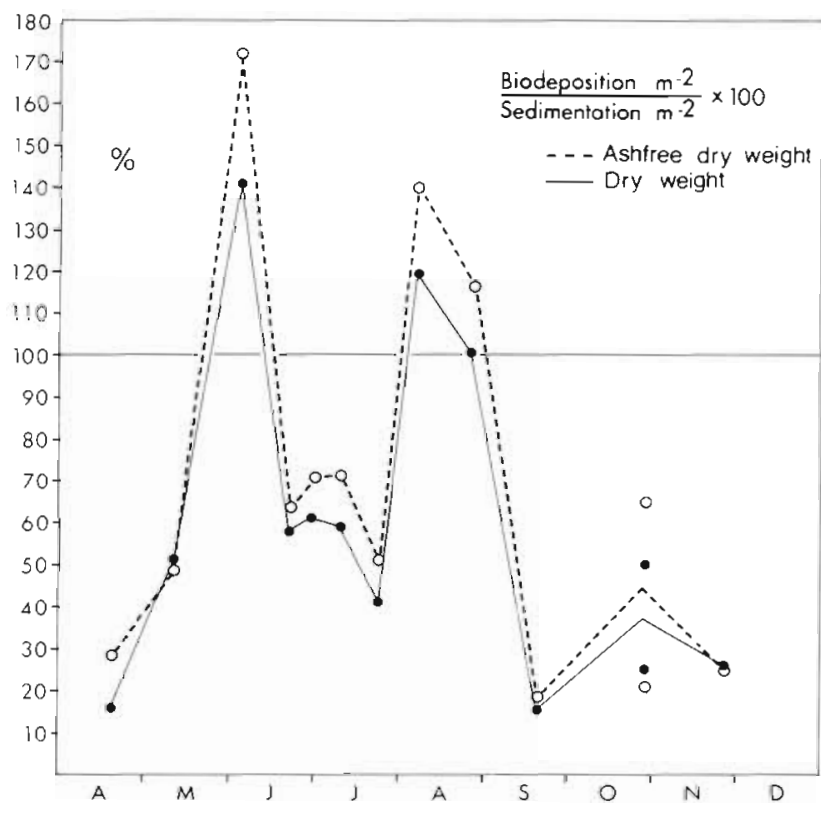

Fig. 3. Calculated percentage contribution of biodeposition to sedimentation load at Vrångskär expressed as dry weight and ashtree dry weight

mussels is high. During this period, the mean organic content of the biodeposits and the naturally sedimented material was $30.4 \pm 2.2 \%$ and $24.8 \pm 1.5 \%$, respectively. During the period of maximum sediment load from October to December, the organic content dropped to $7.8 \pm 2.2 \%$ and $8.7 \pm 2.4 \%$ for the 2 fractions, respectively. A higher proportion of resuspended and mineralized material settling in the traps during rough weather conditions may explain both the drop in organic content and the reduced difference in organic content between the biodeposits and the naturally sedimented material.

The average composition during the year, expressed as percent of dry weight, was $12.88 \pm 2.15 \% \mathrm{C}$ and $1.54 \pm 0.22 \% N(\mathrm{C} / \mathrm{N}=8.4)$ for the biodeposits, compared with $9.92 \pm 0.76 \% \mathrm{C}$ and $1.12 \pm 0.06 \% \mathrm{~N}(\mathrm{C} / \mathrm{N}$ $=8.9$ ) for the naturally sedimented material. For the period April to September, the corresponding values were generally somewhat higher or $14.18 \pm 2.02 \% \mathrm{C}$ and $1.68 \pm 0.20 \% \mathrm{~N}(\mathrm{C} / \mathrm{N}=8.4)$ for the biodeposited and $10.29 \pm 0.74 \% \mathrm{C}$ and $1.20 \pm 0.05 \% \mathrm{~N}(\mathrm{C} / \mathrm{N}=8.6)$ for the naturally sedimented material. The $\mathrm{C} / \mathrm{N}$ ratio was generally slightly lower in the biodeposits than in the sedimented material. Contrary to nitrogen, the average phosphorus content was the same in the biodeposited material and in the sedimenting material, $0.19 \pm 0.02 \%$ and $0.19 \pm 0.01 \%$, respectively, while the mean $\mathrm{C} / \mathrm{P}$ ratio was generally higher for the biodeposits i. e. 76, compared to 55 for the sedimenting matter. The pronounced peak in phosphorus content of the biodeposits in May coincided with the spawning of the mussels.

The mean N/P ratio was 9.2 and 6.4 for the biodeposits and the naturally sedimenting material, respectively. High N/P ratios for both sediment fractions in August coincided with a bloom of nitrogenfixing blue-green algae, which was also recovered in sediment traps suspended at an adjacent pelagic monitoring station (Larsson \& Johansson 1984). The contents of $\mathrm{C}, \mathrm{N}$ and $\mathrm{P}$ as well as the calculated N/P, $\mathrm{C} / \mathrm{N}$ and $\mathrm{C} / \mathrm{P}$ ratios for the naturally deposited material were all in about the same ranges as the corresponding 
Fig. 4. Seasonal variation in carbon, nitrogen and phosphorus of the biodeposits and the naturally sedimenting material at Vrăngskär, $5 \mathrm{~m}$ depth. Values are compared with annual means and ranges for the adjacent pelagic monitoring station, $20 \mathrm{~m}$ depth. (Pelagic data are from Larsson \& Johansson 1984)

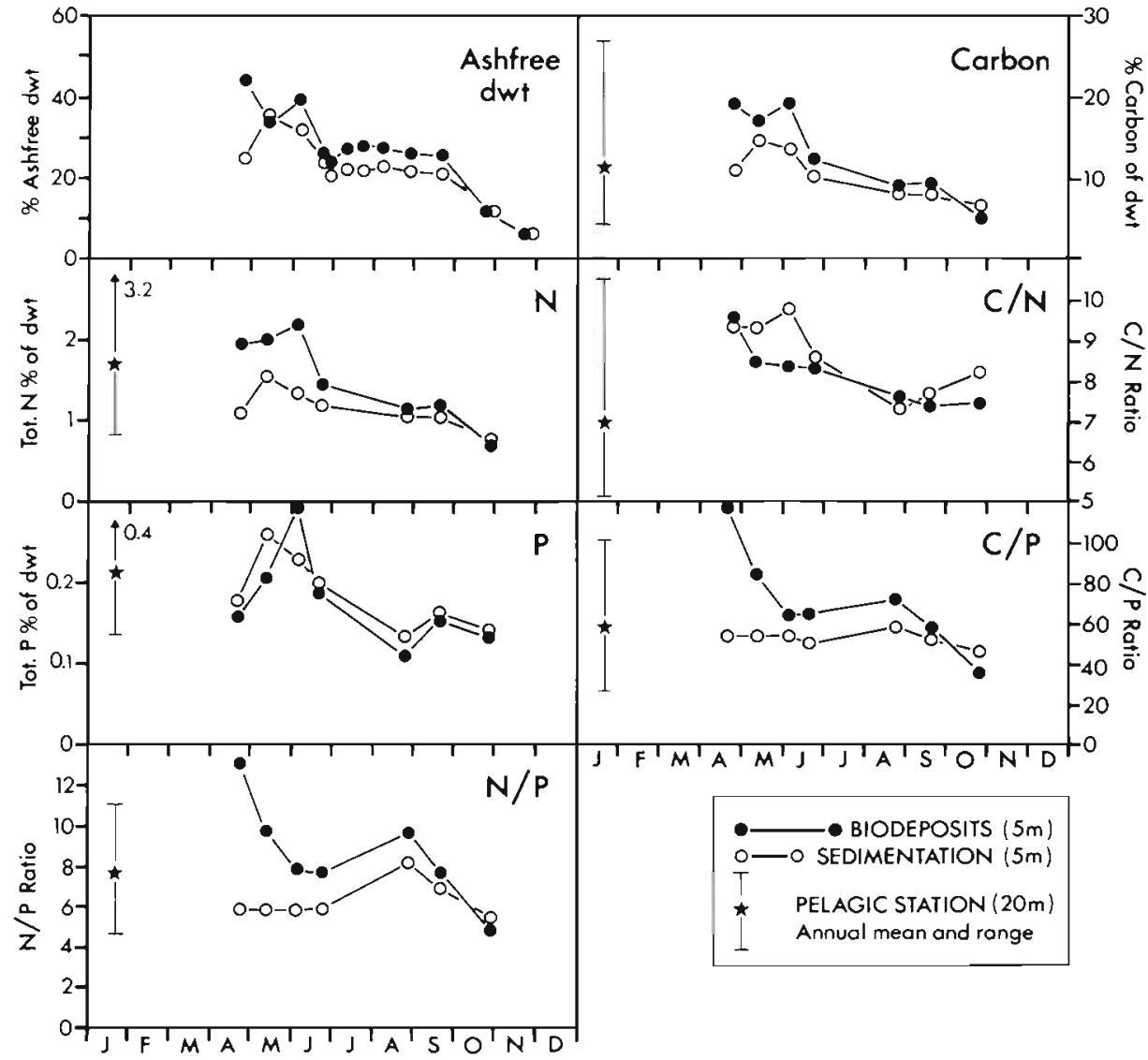

values reported from the pelagic monitoring station by Larsson \& Johansson (1984) (Fig. 4).

In Table 2 daily biodeposition and natural sedimentation at the sampling station are given for different seasonal and annual periods. Assuming mean biodeposition and sedimentation rates of 0.6 and $5 \mathrm{~g}$ $\mathrm{m}^{-2} \mathrm{~d}^{-1}$, respectively for the ice-covered period from January to April when no samples could be obtained, the annual biodeposition and sedimentation at Vrångskär can be estimated as 1100 and $3500 \mathrm{~g}$ dry wt. $\mathrm{m}^{-2}$, respectively. This corresponds to $1.76 \mathrm{~g}$ dry wt. $\mathrm{yr}^{-1}$ per $\mathrm{g}$ mussel including shells or $11.7 \mathrm{~g}$ dry wt. $\mathrm{yr}^{-1}$ per $\mathrm{g}$ mussel shell-free dry wt.

\section{DISCUSSION}

The pronounced seasonality regarding water temperature, water turbulence and phytoplankton biomass in the Baltic will strongly affect the biodeposit production by the mussels and may justify a division of the year into 3 main periods: (1) During January to May water temperature is low, implying low metabolic activity by the mussels and consequently a low biodeposit production (cf. Tsuchiya 1980). Although phytoplankton biomass and pelagic sedimentation are high during the pelagic spring bloom in April, temperature seems to limit biodeposition then. (2) The main productive season for mussels is from the end of May to mid-September. During this period the water temperature will reach its maximum leading to high feeding activity by the mussels which results in high biodeposition rates. Annual blooms of blue-green algae in August will also contribute to the deposition of material rich in organic nitrogen. (3) During September to December the temperature drops thus lowering the metabolic activity of the mussels. The onset of autumn storms will result in the resuspension of refractory material of low organic content, which increases the availability of particles. Even with a lowered filtration activity, the flux of matter will be very high and result in annual peak biodeposition values.

Annual sedimentation in traps suspended in the water column at the pelagic monitoring station in the Askö area (U. Larsson pers. comm.) was 2.5 times lower than in the control traps at Vrångskär (Table 3). However, similar carbon contents and similar $\mathrm{C} / \mathrm{N}$ ratios at the pelagic station and at Vrångskär suggests that the sedimenting material at the 2 stations was of very similar composition. It also indicates that the material in the traps placed on the bottom was not diluted to any extent by resuspended refractory matter when com- 
Table 2. Biodeposition by Mytilus edulis and natural sedimentation at the sampling station during different seasons (weighted means and total) and for the whole year. For percentages of ashfree dry wt and $C, N$, $P$ during 1 Jan to 1 Apr, values from the preceding period (1 Oct to $31 \mathrm{Dec}$ ) have been used

\begin{tabular}{|c|c|c|c|c|c|c|c|c|c|c|c|c|c|c|}
\hline & \multicolumn{3}{|c|}{$\begin{array}{c}1 \text { Apr-14 Jun } \\
(76 \mathrm{~d}) \mathrm{n}=3\end{array}$} & \multicolumn{3}{|c|}{$\begin{array}{c}15 \text { Jun-30 Sep } \\
(107 d) n=7\end{array}$} & \multicolumn{3}{|c|}{$\begin{array}{c}1 \text { Oct-31 Dec } \\
(90 \mathrm{~d}) \mathrm{n}=3\end{array}$} & \multicolumn{3}{|c|}{$\begin{array}{c}1 \text { Jan-31 Mar } \\
(90 \mathrm{~d}) \mathrm{n}=0\end{array}$} & \multicolumn{2}{|c|}{$\begin{array}{l}1 \mathrm{Jan}-31 \mathrm{Dec} \\
(365 \mathrm{~d}) \mathrm{n}=13\end{array}$} \\
\hline & $\begin{array}{c}\text { Mean } \\
d^{-1}\end{array}$ & Total & $\%$ & $\begin{array}{c}\text { Mean } \\
d^{-1}\end{array}$ & Total & $\%$ & $\frac{\text { Mean }}{d^{-1}}$ & Total & $\%$ & $\begin{array}{c}\text { Mean } \\
d^{-1}\end{array}$ & Total & $\%$ & $\begin{array}{l}\text { Total } \\
\left(\mathrm{yr}^{-1}\right)\end{array}$ & $\%$ \\
\hline \multicolumn{15}{|c|}{ Biodeposition $^{*}\left(\mathrm{~g} \mathrm{~m}^{-2}\right\}$} \\
\hline Dry wt & 0.776 & 58.99 & & 3.861 & 409.21 & & 6.175 & 568.12 & & $0.62^{\cdots}$ & 55.80 & & 1092.2 & \\
\hline Ashfree dry wt & 0.308 & 23.40 & 39.7 & 1.007 & 107.74 & 26.3 & 0.640 & 58.86 & 10.4 & 0.064 & 5.78 & 10.4 & 195.7 & 17.9 \\
\hline C & 0.144 & 10.99 & 18.6 & 0.353 & 37.88 & 9.2 & 0.315 & 28.97 & 5.1 & 0.032 & 2.85 & 5.1 & 80.7 & 7.4 \\
\hline$N$ & 0.006 & 1.26 & 2.1 & 0.046 & 4.90 & 1.2 & 0.042 & 3.87 & 0.7 & 0.004 & 0.38 & 0.7 & 10.4 & 0.9 \\
\hline$P$ & 0.001 & 0.14 & 0.2 & 0.005 & 0.58 & 0.1 & 0.001 & 0.79 & 0.1 & 0.001 & 0.08 & 0.1 & 1.6 & 0.1 \\
\hline \multicolumn{15}{|c|}{ Sedimentation $\left(\mathrm{g} \mathrm{m}^{-2}\right)$} \\
\hline Dry wt & 1.724 & 131.02 & & 7.090 & 751.90 & & 23.790 & 2188.7 & & $5^{\cdots}$ & 450 & & 3521.2 & \\
\hline Ashfree dry wt & 0.535 & 40.64 & 31.0 & 1.559 & 166.83 & 22.2 & 2.555 & 235.07 & 10.7 & 0.537 & 48.33 & 10.7 & 490.9 & 13.9 \\
\hline C & 0.217 & 16.48 & 12.6 & 0.592 & 63.36 & 8.4 & 1.494 & 137.45 & 6.3 & 0.314 & 28.26 & 6.3 & 245.5 & 7.0 \\
\hline $\mathrm{N}$ & 0.023 & 1.74 & 1.3 & 0.077 & 8.26 & 1.1 & 0.183 & 16.81 & 0.8 & 0.038 & 3.46 & 0.8 & 30.3 & 0.9 \\
\hline P & 0.004 & 0.30 & 0.2 & 0.011 & 1.15 & 0.1 & 0.033 & 3.06 & 0.1 & 0.007 & 0.63 & 0.1 & 5.1 & 0.1 \\
\hline
\end{tabular}

Table 3. Sedimentation and biodeposition by Mytilus edulis (per $\mathrm{g}$ mussel and per $\mathrm{m}^{2}$ ) at experimental site and for the total research area. Deposition values calculated as weighted means for the productive season and for the whole year. Average mussel biomass at site is $620 \mathrm{~g} \mathrm{~m}^{-2}$ and for the total $160 \mathrm{~km}^{2}$ research area $63.7 \mathrm{~g} \mathrm{~m}^{-2}$ (Kautsky 1981b)

\begin{tabular}{|c|c|c|c|c|c|c|c|c|c|}
\hline & & Period & Dry wt & $\begin{array}{c}\text { Ashfree dry } \\
\text { wt }(\%)\end{array}$ & $\mathrm{C}$ & $\% \mathrm{C}$ & $N$ & $\mathrm{P}$ & $\mathrm{C} / \mathrm{N}$ \\
\hline Sedimentation & $g \mathrm{~m}^{-2}$ & 1 Apr -30 Sep & 882.5 & 23.5 & 79.8 & 9.0 & 10.00 & 1.45 & 7.98 \\
\hline$(0-5 \mathrm{~m})$ & $\mathrm{g} \mathrm{m}^{-2}$ & $1 \mathrm{Jan}-31 \mathrm{Dec}$ & 3521.2 & 13.9 & 245.5 & 7.0 & 30.27 & 5.14 & 8.11 \\
\hline Sedimentation ${ }^{\circ}$ & $\mathrm{g} \mathrm{m}^{-2}$ & 1 Apr-30 Sep & 208.5 & - & 31.7 & 15.2 & 3.77 & 0.49 & 8.41 \\
\hline$(0-20 \mathrm{~m})$ & $\mathrm{g} \mathrm{m}^{-2}$ & $1 \mathrm{Jan}-31 \mathrm{Dec}$ & 1401.2 & - & 91.7 & 6.5 & 10.66 & 1.64 & 8.60 \\
\hline Biodeposition & $\mathrm{mg} \mathrm{g}^{-1}$ & $1 \mathrm{Apr}-30 \mathrm{Sep}$ & 755.2 & 28.0 & 78.7 & 10.4 & 9.94 & 1.16 & 7.92 \\
\hline (5 $\mathrm{m}$ depth) & $\operatorname{mg~g}{ }^{-1}$ & $1 \mathrm{Jan}-31 \mathrm{Dec}$ & 1761.6 & 17.9 & 130.1 & 7.4 & 16.80 & 2.56 & 7.74 \\
\hline Biodeposition & $g m^{-2}$ & $1 \mathrm{Apr}-30 \mathrm{Sep}$ & 468.2 & 28.0 & 48.8 & 10.4 & 6.16 & 0.72 & 7.92 \\
\hline (5m depth) & $\mathrm{g} \mathrm{m}^{-2}$ & $1 \mathrm{Jan}-31 \mathrm{Dec}$ & 1092.2 & 17.9 & 80.7 & 7.4 & 10.42 & 1.59 & 7.74 \\
\hline Biodeposition & $g \mathrm{~m}^{-2}$ & $1 \mathrm{Apr}-30 \mathrm{Sep}$ & 48.1 & 28.0 & 5.0 & 10.4 & 0.63 & 0.07 & 7.92 \\
\hline (total area) & $g \mathrm{~m}^{-2}$ & $1 \mathrm{Jan}-31 \mathrm{DeC}$ & 112.2 & 17.9 & 8.3 & 7.4 & 1.07 & 0.16 & 7.74 \\
\hline
\end{tabular}

pared to the freely suspended traps at the pelagic station. The differences in total amounts of sedimented material would rather reflect a much higher biological activity in littoral areas and a continuous resuspension of recently settled sedimenting material, such as algal detritus and fresh faecal pellets.

Deposits will never remain long on the wave-swept rocky bottoms of the Askö area, and one major difference between faeces settling in these erosion areas and in our traps is that the latter are protected from resuspension and will continuously accumulate. A significant part of the material collected in the pelagic traps may also be derived from resuspended matter. In sev- eral coastal areas resuspension has been found to contribute more to sedimentation than deposition of fresh primary settling particles from the water column (Steele \& Baird 1972, Oviatt \& Nixon 1975, Zeitzschel 1980, Kelly \& Nixon 1984). Furthermore, Newell et al. (1982) found that the suspended particulate material in a kelp area was composed of phytoplankton, benthic algal detritus and mussel faeces in about equal parts

Large differences in quality were found between the sediment in mussel traps and the naturally sedimenting matter. This was also found in mussel farming areas, where Dahlbäck and Gunnarsson (1981), Tenore et al. (1982) and Kaspar et al. (1985) observed that mussel 
biodeposition changed the characteristics of the sediment under the farms. The sediment under mussel cultures had a finer texture, lower bulk density and higher water content than at an adjacent reference station (Dahlbäck \& Gunnarsson 1981, Kaspar et al 1985). Sediment phaeophytin levels beneath the mussel lines were always several times higher than outside the culture, suggesting a high sedimentation of algal decay products, possibly through conversion of chlorophyll a to phaeopigments during grazing (Currie 1962). The mussel biodeposits in the present study also had a finer texture and darker colour than the naturally sedimented material; if stirred, they turned into a colloidal suspension that settled extremely slowly, while the naturally sedimenting material quickly flocculated and settled out again.

High sedimentation rates near mussel suspension cultures may result in accumulation of organic matter, which is followed by increased oxygen consumption, anoxia and denitrification (Kaspar et al. 1985) and increased sulphate reduction (Dahlbäck \& Gunnarsson 1981). Despite nitrogen losses through higher rates of denitrification and nitrogen mineralization in mussel farm sediments (Kaspar et al. 1985), the accumulation of organic nitrogen relative to organic carbon and phosphorus was indicated by lower organic $\mathrm{C} / \mathrm{N}$ ratios and higher organic N/P ratios.

While percentage carbon in detritus and faeces generally decreases with age during decay as a result of respiratory losses of $\mathrm{CO}_{2}$, percentage nitrogen will generally increase (review in Valiela 1984). Dahlbäck \& Gunnarsson (1981) found no difference in $\mathrm{C} / \mathrm{N}$ ratios of fresh $(<3 \mathrm{~d}$ old) sedimenting material collected under suspended mussel culture and outside this area. However, the $\mathrm{C} / \mathrm{N}$ ratios of the sedimenting particles under the culture were always higher (12 to 14) than those in the top layer of the deposited sediment under the culture ( 6 to 9). They interpreted the higher $\mathrm{C} / \mathrm{N}$ values for the sedimenting particles as a result of faster degradation and recycling of nitrogen compared to carbon when phytoplankton is the food of mussels and when the faecal material is exposed to microbial degradation. They suggested that the lower $\mathrm{C} / \mathrm{N}$ ratios in the top layer of the sediment are explained by a higher bacterial biomass. This implies that the sedimenting faeces will undergo very rapid microbial changes. One factor speeding up this process may be that faeces at deposition are already enriched by bacteria (especially Vibrio) that survive and may multiply when passing through the digestive system of the mussel (Prieur 1981). Bacterial activity is also enhanced by the enlarged surface area of the fine particles composing the faecal pellets (Fenchel 1970).

No literature was found on changes in phosphorus contents during decay. We suggest the decrease in organic P in faeces compared with natural sedimentation may be due to leaching from cells that are ruptured and fragmented during passage through the gut.

Organic matter deposited as faeces may represent a significant proportion of the energy potentially available to consumer invertebrates as a food resource (Stuart et al. 1982). The nitrogen content of food has been regarded as an important indicator of its nutritional value (Russel-Hunter 1970, Boyd \& Goodyear 1971). Material with a $\mathrm{C} / \mathrm{N}$ ratio of 5.5 is considered typical of bacteria (Fenchel \& Blackburn 1979). C/N ratios between 4 and 8 indicate phytoplankton, faecal pellets and other easily degraded material of high nutritional value, whereas $\mathrm{C} / \mathrm{N}$ ratios of 10 or greater characterize detritus, sediment or other mineralized material of low nutritional value (Strickland 1960, Parsons et al. 1977). Fresh detritus is often low in nitrogen and $\mathrm{C} / \mathrm{N}$ values of 15 to 60 are not unusual in detritus from vascular plants in salt marshes and eelgrass. On this basis, the biodeposits at Vrångskär with a $\mathrm{C} / \mathrm{N}$ ratio of about 8 may be classified as of high nutritional value.

It is generally accepted that e.g. vascular plant detritus first must be colonized by microbial decomposers to increase the nitrogen content and lower $\mathrm{C} / \mathrm{N}$ ratios before it becomes suitable as food for consumers. After ingestion the microbes are stripped from the inert detrital particles which are subsequently returned to the environment for further microbial recolonization and possibly reingestion (e.g. Newell 1965, Fenchel 1972, Hargrave 1976, Levinton \& Lopez 1977).

Coprophagy has been observed in most deposit feeders (Frankenberg et al. 1967), and the palatability of faeces was shown to be related directly to carbon and nitrogen contents (Frankenberg \& Smith 1967). Since these were higher in the biodeposits than in naturally sedimenting material, the faeces should be attractive as a food source.

However, microbial nitrogen is not enough to account for all of the nitrogen recovered in aged detritus (Odum et al. 1979, Cammen 1980a, b). Significant amounts are probably also due to microbial accumulation of extracellular protein and nitrogencontaining exudates (Glenn 1976, Hobbie \& Lee 1980) and through binding of proteinaceous substances by phenolic compounds in the detritus (Tenore \& Rice 1980, Rice 1982). Since the nitrogen bound to phenolic compounds is not easily available to consumers (Odum et al. 1979, Rice 1982), the detritus may have a lower food value than indicated by its $\mathrm{C} / \mathrm{N}$ ratio (Tenore et al. 1979, Tenore \& Rice 1980, Robinson et al. 1982).

Nevertheless, benthic filter feeders seem to serve as important agents stimulating bacterial growth that provide the benthos with nutritious food. Biodeposition clearly represents a food source for benthic deposit 
feeders and will increase both the quantity and the quality of sedimenting material. This is indicated by the fact that species diversity and biomasses of depositfeeders and meiofauna are generally higher in mussel beds than on adjacent bottoms without mussels (Kautsky 1974, Tsuchiya \& Nishihira 1985, Radziejewska 1986). This is probably true for most natural mussel beds where the water exchange is sufficient to prevent oxygen deficiency. However, in a mussel culturing area where water exchange is limited the situation may be quite different since the mussels are suspended in the water with a good food supply and water movement, while the faeces will sink and accumulate on the bottom. In this case increased benthic microbial activity will often result in oxygen depletion and low macrofauna diversity as shown by Mattson \& Lindén (1983), Tenore et al. (1982) and Kaspar et al. (1985).

Bertness (1984) found that the faecal material from Geukensia demissa stimulated growth of Spartina alterniflora on which the mussels were attached. This emphasizes the stimulating effect of biodeposition also on benthic plant production, and mussels may then in an indirect way provide food also for pelagic and epibenthic predators.

About half of the particulate nitrogen and carbon consumed by mussels is expelled as faeces (Jordan \& Valiela 1982, Hawkins \& Bayne 1985), while the corresponding figure for phosphorus may be as high as $94 \%$ (Kuenzler 1961a). Although bacterial activity could, at least theoretically, explain the higher nitrogen content of mussel faeces compared to naturally sedimenting material, it could not explain the observed higher carbon contents. These were obtained even after ageing of the sediment which should result in a lowering of its total carbon content.

It is known that faeces produced by deposit feeders will generally have a higher organic content than the surrounding sediment, since many species are able to actively sort out organic particles from the sand (Fenchel \& Lappalainen 1975, Hylleberg \& Gallucci 1975). Such particle selection has been observed also in suspension-feeding mussels, which seem to be able to discriminate between inorganic and organic particles, sorting out those of low food value and discarding them as pseudofaeces that do not pass through the intestine (Kiørboe et al. 1980, Kiørboe \& Mohlenberg 1981). However, since these particles are removed from the water, compacted with mucus and then deposited together with the faeces, the organic content of the mussel biodeposits will not be affected.

Thus, considering that the biodeposits have passed the alimentary tract of mussels and that the organic matter has been partly digested, especially the higher carbon contents are puzzling. We believe that this is because the mussels utilize quite another size fraction of the pelagic particles, which is particularily rich in organic carbon and nutrients, compared to that sedimenting naturally. To illustrate this we have compiled some relevant date in Fig. 5 on the size distribution of

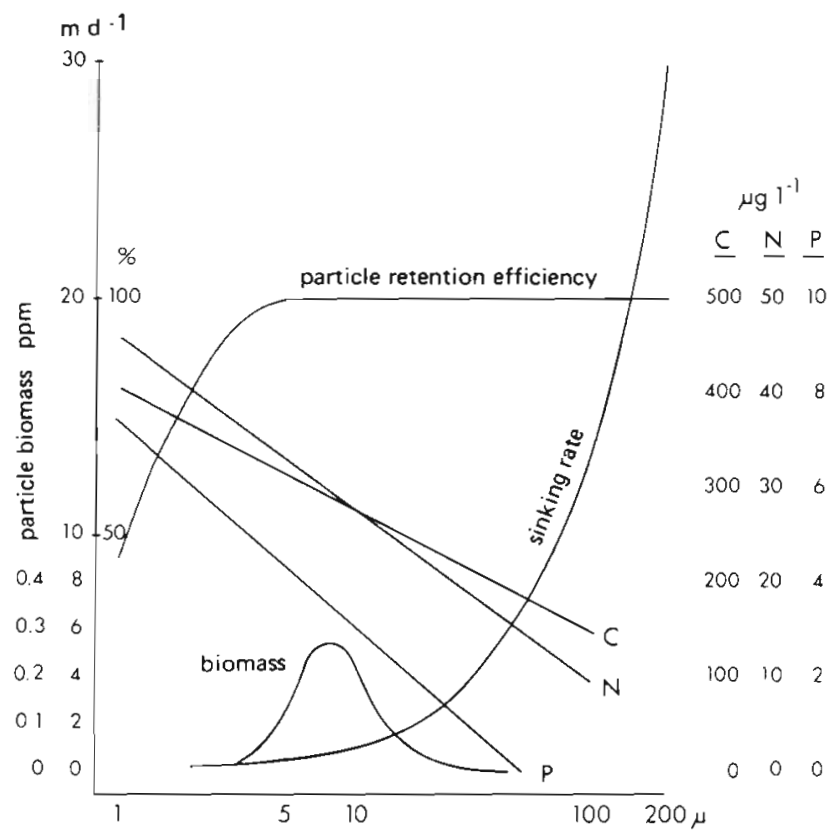

Fig. 5. Compilation of data concerning size distribution sinking rates and contents of carbon, nitrogen and phosphorus for different size fractions of particulate suspended material, and retention efficiency by Mytilus edulis. Data for size distribution from F. Wulff (pers. comm.), sinking rates from Simpson (1982), CNP contents from Mullin (1965) and Bienfang (1984), particle retention from Møhlenberg \& Riisgård (1978) and Stuart \& Klumpp (1984)

particles in the Askö area with literature data on sinking rates and contents of carbon, nitrogen and phosphorus for different size fractions of particulate suspended material, as well as the retention efficiency of Mytilus edulis.

Small particles generally dominate in the sea. In the Askö area the bulk of the suspended particles has a size of less than $12 \mu \mathrm{m}$ and the annual variation in the particle size distribution is small ( $F$. Wulff pers. comm.). Under conditions similar to those experienced by Baltic mussels in algal belts, Stuart \& Klumpp (1984) found that more than $80 \%$ of the particulate material (by volume) falls in the size range of 0.5 to $20 \mu \mathrm{m}$ and that the smallest particles were richest in nitrogen. Mullin (1965) observed that the carbon content in seston of 1 to $10 \mu \mathrm{m}$ size particles was much higher than in all the larger particle sizes combined and Bienfang (1984) found that the majority of particulate chlorophyll, carbon, nitrogen and phosphorus in subarctic waters was recovered in the $<5 \mu \mathrm{m}$ size fraction. Consequently, 
small naturally occurring particles, probably with a high contribution from living cells (e.g. bacteria and naked flagellates), seem to dominate the suspended material in coastal waters. Due to this higher food value of such small particles it will obviously be advantageous for a suspension feeder to remove these as efficiently as possible (Stuart \& Klumpp 1984).

While the natural sedimentation rate increases exponentially with particle size (Simpson 1982), the filtration activity of mussels will retain completely all particles down to $4 \mu \mathrm{m}$ and with decreasing efficiency sizes down to less than $1 \mu \mathrm{m}$ (Vahl 1972, Møhlenberg \& Riisgård 1978, Stuart \& Klumpp 1984). Taking into account that filter feeding and biodeposition are active processes compared to passive natural sedimentation, which depends on the size of the particles, it is clear that mussels from a natural pool of particles will remove large amounts of very small suspended particles that would not easily settle by themselves.

From the above data we can theoretically calculate the relative importance of biodeposition and natural sedimentation for the removal of different size fractions of matter suspended in the water mass (Fig. 6). Assuming complete mixing and an unlimited supply of particles in the water mass with the size distribution given in Fig. 5, a mussel biomass of $64 \mathrm{~g} \mathrm{~m}^{-2}$ (i.e. the average

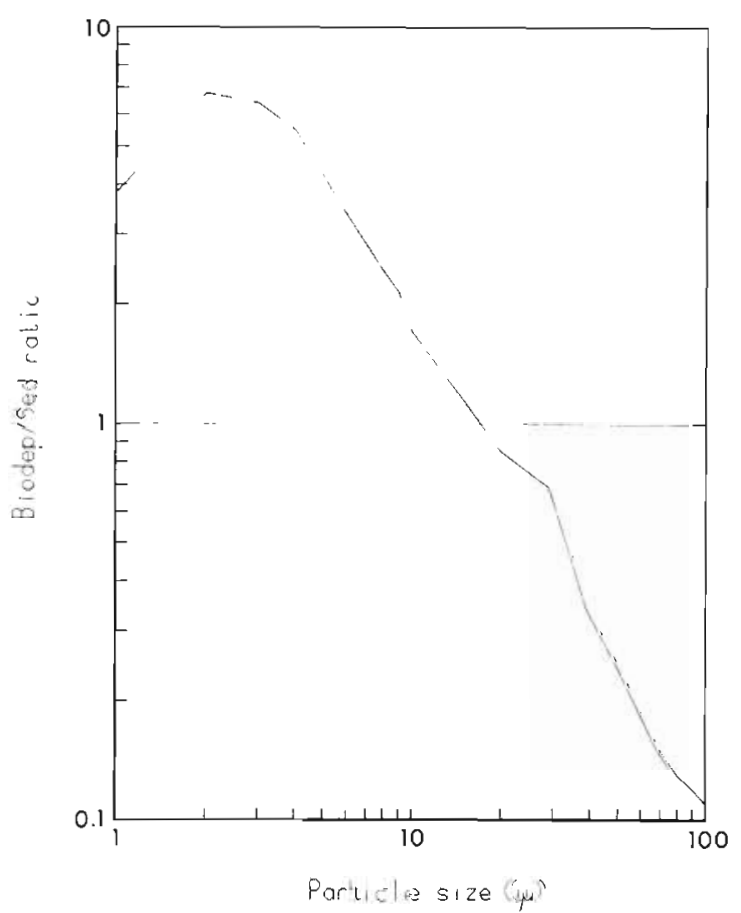

Fig. 6. Calculated biodeposition to sedimentation ratio for different particle sizes of suspended material at an average mussel biomass of $64 \mathrm{~g} \mathrm{~m}^{-2}$ with an estimated filtration capacity of $1.1 \mathrm{l} \mathrm{g}^{-1} \mathrm{~h}^{-1}$ and using the relations given in Fig. 5 for filtration efficiency, sedimentation rates and particles size spectrum in the water mass for the total Askö area), with a filtration rate of 1.121 $\mathrm{g}^{-1} \mathrm{~h}^{-1}$ (Møhlenberg \& Riisgård 1979), the model shows that biodeposition and sedimentation are equally large for particles of about 18 um size. Smaller particles may have up to 7 times higher chance of getting caught by mussels, while with increasing size of the particles the fraction sedimenting out too quickly to be captured will increase rapidly.

After deposition faecal material is very easily resuspended due to its low density and high water content (Stuart et al. 1982) and may give rise to significant amounts of small particles of 'bioseston' in the size range 1.5 to $8.4 \mu \mathrm{m}$ (Vahl 1972, Hildreth 1980), possibly consisting of bacterial aggregates, ruptured phytoplankton cells and fragmented detritus particles. This means that the mussels do not only initiate the sedimentation of small particles, but that they also produce small particles, with a lower settling velocity, from larger ones.

At Vrångskär, the benthos annually receives about $81 \mathrm{~g}$ carbon, $10 \mathrm{~g}$ nitrogen and $2 \mathrm{~g}$ phosphorus per $\mathrm{m}^{2}$ as a result of the feeding activity of mussels (Table 2). These values can be compared with $245 \mathrm{~g}$ carbon, $30 \mathrm{~g}$ nitrogen and $5 \mathrm{~g}$ phosphorus additionally received due to natural sedimentation. For the total $160 \mathrm{~km}^{2}$ primary research area outside the Askö Laboratory, the annual sedimentation from the water column can be calculated at about 15000 tons of carbon, 1700 tons of nitrogen, and 260 tons of phosphorus (from Table 3). With a total mussel biomass of about 10000 tons in the area (Jansson \& Kautsky 1977), the additional annual contribution from mussel biodeposition would be 1300 tons of carbon, 170 tons of nitrogen and 26 tons of phosphorus, which means that the total annual deposition of $\mathrm{C}, \mathrm{N}$ and $\mathrm{P}$ is increased by about $10 \%$ by the mussels.

Earlier measurements of nutrient excretion from Mytilus edulis by Kautsky \& Wallentinus (1980) indicated that the mussel population in the Askö area annually regenerates 339 tons of inorganic nitrogen and 104 tons of inorganic phosphorus. This is well in excess of the demands of the benthic algae and can explain why many of these can extend their growth maximum after the spring phytoplankton bloom, making use of the improved light conditions while being fertilized from the mussels, at a time when nutrients are depleted in the water mass due to phytoplankton growth (Kautsky \& Wallentinus 1980). Nonetheless, after the benthic algae were supplied with their needs, the remaining nutrients amounting to 252 tons of $\mathrm{N}$ and 99 tons of $P$ could supply the pelagic zone with an estimated $6 \%$ of its annual nitrogen and $17 \%$ of its annual P demand (Kautsky \& Wallentinus 1980).

To this we can now add the nutrients supplied at a somewhat slower rate through decomposition of biodeposits, which are completely mineralized within 
about $30 \mathrm{~d}$ at $10^{\circ} \mathrm{C}$ (Stuart et al. 1982). Thus in total it can be estimated that the mussels annually circulate 510 tons $\mathrm{N}$ and 130 tons $\mathrm{P}$, corresponding to the total needs for benthic algal production and additionally about 12 and $22 \%$, respectively, of the $N$ and $P$ demands for pelagic production. This nutrient input is probably even more important than the figures show since these are annual mean values, while in reality this is an input mainly in summer when mussel activity is at its highest and nutrients are limiting to primary production. Moreover, because the main distribution of mussels is above the summer thermocline at about 15 m depth, the nutrients regenerated by mussels are released directly into the trophogenic zone where they are immediately available to primary production. In comparison, naturally sedimenting plankton and matter will be deposited mainly on soft bottoms where it is accumulated or remineralized primarily through detrital pathways, which are known to be slower than those typical of direct consumption by animals (Verhoff \& DePinto 1977). Furthermore, nutrients released from the deeper soft bottoms are generally not so easily accessible to the trophogenic zone because mixing and vertical transport are often reduced by physical constraints such as the development of thermo- and haloclines.

Acknowledgements. This study was carried out with support from the Swedish Natural Research Council. We are grateful to Drs Ulf Larsson and Fredrik Wulff for unpublished data and to Drs Ragnar Elmgren and Sif Johansson for valuable comments on the manuscript.

\section{LITERATURE CITED}

Ahlgren, G. (1976). Jämförelse mellan olika metoder för bestämning av totalfosfor i naturvatten. Vatten 32: 38-44

Bertness, M. D. (1984). Ribbed mussels and Spartina alterniflora production in a New England salt marsh. Ecology 65 : 1794-1807

Bienfang, P. K. (1984). Size structure and sedimentation of biogenic microparticulates in a subarctic ecosystem. J. Plankton Res. 6: 985-995

Biggs, R. B., Howell, B. A. (1984). The estuary as a sediment trap: alternative approaches to estimating its filtering efficiency. In: Kennedy, V. S. (ed.) The estuary as a filter Proc. 7 th Biennial Int. Estuarine Res. Conf., Virginia Beach, Virginia, October 23-26, 1983, p. 107-129

Black, L. F. (1982). The biodeposition cycle of a surface deposit feeding bivalve, Macoma balthica (L.). In: Kennedy, V. S. (ed.) Estuarine perspectives. Academic Press, London, p. 389-399

Boyd, C. E., Goodyear, C. P. (1971). Nutritive quality of food in ecological systems. Arch. Hydrobiol. 69: 256-270

Cammen, L. M. (1980a). Ingestion rate: an empirical model for aquatic deposit feeders and detrivores. Oecologia (Berl.) 44: 303-310

Cammen, L. M. (1980b). The significance of microbial carbon in the nutrition of the deposit feeding polychaete Nereis succinea. Mar. Biol. 61: 9-20

Cloern, J. E. (1982). Does the benthos control phytoplankton biomass in South Sán Francisco Bay? Mar. Ecol. Prog. Ser. 9: 191-202

Currie, R. I. (1962). Pigments in zooplankton faeces. Nature, Lond. 193: 956-957

Dahlbäck, B., Gunnarsson, L. H. (1981). Sedimentation and sulfate reduction under a mussel culture. Mar. Biol. 63: 269-275

Elmgren, R. (1984). Trophic dynamics in the enclosed, brackish Baltic Sea. Rapp. P.-v. Reun. Cons. int. Explor. Mer 183: 152-169

Fenchel, T. (1970). Studies on the decomposition of organic detritus derived from the turtle grass Thalassia testudinum. Limnol. Oceanogr. 15: 14-20

Fenchel, T (1972). Aspects of decomposer food chains in marine benthos. Verh. dt. zool. Ges. 14: 14-22

Fenchel, T., Lappalainen, A. (1975). Particle size-selection of two deposit-feeders: the amphipod Corophium volutator and the mesobranch Hydrobia ulvae. Mar. Biol. 30: $119-128$

Fenchel, T, Blackburn, T H. (1979). Bacteria and mineral cycling. Academic Press, London

Frankenberg, D., Coles, S. L., Johannes, R. E. (1967). The potential trophic significance of Callianassa major fecal pellets. Limnol, Oceanogr. 12: 113-120

Frankenberg, D., Smith, K. L. (1967). Coprophagy in marine animals. Limnol. Oceanogr. 12: 443-450

Frechette, M., Bourget, E. (1985). Energy flow between the pelagic and benthic zones: factors controlling particulate organic matter available to an intertidal mussel bed. Can. J. Fish. Aquat. Sci. 42: 1158-1165

Glenn, A. R. (1976). Production of extracellular protein by bacteria. A. Rev. Microbiol. 30: 41-62

Hargrave, B. T. (1976). DDT residues in benthic invertebrates and demersal fish in St. Margarets Bay, Nova Scotia. J. Fish. Res. 33: 1692-1698

Haven, D. S., Morales-Alamo, R. (1966). Aspects of biodeposition by oysters and other invertebrate filter feeders. Limnol. Oceanogr. 11: 487-498

Haven, D. S., Morales-Alamo, R. (1972). Biodeposition as a factor in sedimentation of five suspended solids in estuaries. Mem geol. Soc. Am. 133: 121-130

Hawkins, A. J. S., Bayne, B. L. (1985). Seasonal variation in the relative utilization of carbon and nitrogen by the mussel Mytilus edulis: budgets, conversion efficiencies and maintainance requirements. Mar. Ecol. Prog. Ser. 25: 181-188

Hildreth, D. J. (1980). Bioseston production by Mytilus edulis and its effect in experimental systems. Mar Biol. 55 309-315

Hobbie, J. E., Lee, C. (1980). Microbial production of extracellular material: importance in benthic ecology. In: Coull, B. C., Tenore, K. R. (ed.) Marine benthic dynamics. Univ. South Carolina Press, Columbia, p. 341-346

Hylleberg, J., Gallucci, V. F. (1975). Selectivity in feeding by the deposit-feeding bivalve Macoma nasuta. Mar. Biol. 32: $167-178$

Jansson. A.-M., Kautsky, N. (1977). Quantitative survey of hard bottom communities in a Baltic archipelago. In: Keegan, B. F., O'Ceidigh, P., Boaden, P. J. S. (ed.) Biology of benthic organisms. 11th Europ. Symp. Mar. Biol., Galway, Ireland, Oct. 1976, p. 359-366

Johannes, R. E., Satomi, M. (1966). Composition and nutritive value of fecal pellets of a marine crustacean. Limnol Oceanogr. 11. 191-197

Jordan, T. E., Valiela, J. (1982). A nitrogen budget of the 
ribbed mussel Geukensia demissa and its significance in nitrogen flow in a New England salt marsh. Limnol. Oceanogr 27: 75-90

Kaspar, H. F., Gillespie, P. A., Boyer, I. C., MacKenzie, A. L. (1985). Effects of mussel aquaculture on the nitrogen cycle and benthic communities in Kenepuru Sound, Marlborough Sounds. New Zealand. Mar. Biol. 85: 127-136

Kautsky, N. (1974). Quantitative investigations of the red algal belt in the Askö area, Northern Baltic proper. Contrib. Askö Lab. Univ. Stockholm, p. 1-29

Kautsky, N., Wallentinus, I. (1980). Nutrient release from a Baltic Mytilus-red algal community and its role in benthic and pelagic productivity. Ophelia (Suppl. 1): 17-30

Kautsky, N. (1981a). On the trophic role of the blue mussel (Mytilus edulis L.) in a Baltic coastal ecosystem and the fate of the organic matter produced by the mussels. Kieler Meeresforsch. (Sonderh.) 5: 454-461

Kautsky, N. (1981b). On the role of the blue mussel Mytilus edulis L. in the Baltic ecosystem. Thesis summary, Univ. Stockholm, Sweden

Kautsky, N. (1982a). Quantitative studies on gonad cycle, fecundity, reproductive output and recruitment in a Baltic Mytilus edulis population. Mar. Biol. 68: 143-160

Kautsky, N. (1982b). Growth and size structure in a Baltic Mytilus edulis population. Mar. Biol. 68: 117-133

Kelly, J. R., Nixon, S. W. (1984). Experimental studies of the effect of organic deposition on the metabolism of a coastal marine bottom community. Mar. Ecol. Prog. Ser. 17: $157-169$

Kiørboe, T., Møhlenberg, F., Nøhr, O. (1980). Feeding, particle selection and carbon absorption in Mytilus edulis in different mixtures of algae and resuspended bottom materials. Ophelia 19: 193-205

Kiørboe, R., Møhlenberg, F. (1981). Particle selection in suspension-feeding bivalves. Mar. Ecol. Prog. Ser. 5: 291-296

Kraeuter, J. N. (1976). Biodeposition by salt-marsh invertebrates. Mar Biol. 35: 215-223

Kuenzler, E. J. (1961a). Phosphorous budget of a mussel population. Limnol. Oceanogr 6: 400-415

Kuenzler, E. J. (1961b). Structure and energy flow of a mussel population in a Georgia salt marsh. Limnol. Oceanogr, 6: $191-204$

Larsson, U., Johansson, S. (1984). Himmerfjärdsundersökningen. Report to SYVAB. Mimeogr. Askö Laboratory, Univ. Stockholm

Levinton, J. S., Lopez, G. R. (1977). A model of renewable resources and limitation of deposit-feeding benthic populations. Oecologia 31. 177-190

Mattsson, J., Lindén, O. (1983). Benthic macrofauna succession under mussels, Mytilus edulis L. (Bivalvia), cultured on hanging long-lines. Sarsia 68: 97-102

Møhlenberg, F., Ruisgård, H. U. (1978). Efficiency of particle retention in 13 species of suspension feeding bivalves. Ophelia 17: 239-246

Møhlenberg, F., Riisgård, H. U. (1979). Filtration rate, using a new indirect technique in 13 species of suspension feeding bivalves. Mar. Biol. 84: 143-148

Mullin, M. M. (1965). Size fractionation of particulate organic carbon in the surface waters of the western Indian Ocean. Limnol. Oceanogr. 10: 459-462

Newell, R. C. (1965). The role of detritus in the nutrition of two marine deposit feeders, the prosobranch Hydrobia ulvae and the bivalve Macoma balthica. Proc. Zool. Soc. Lond. 144: $25-45$

Newell, R. C., Field, J. G., Griffiths, C. L. (1982). Energy balance and significance of microorganisms in a kelp bed community. Mar. Ecol. Prog. Ser. 8: 103-113
Odum, W. E., Kirk, P. W., Zieman, J. C. (1979). Non-protein nitrogen compounds associated with particles of vascular plant detritus. Oikos 32: 363-367

Officer, C. B., Smayda, T J., Mann, R. (1982). Benthic filter feeding: a natural eutrophication control. Mar. Ecol. Prog. Ser. 9: $303-210$

Oviatt, C. A., Nixon, S. W. (1975). Sediment resuspension and deposition in Narragansett Bay. Estuar. coast. mar Sci. 3: 201-217

Parsons, T R., Takahashi, M., Hargrave, B. (1977). Biological oceanographic processes, 2nd edn. Pergamon Press, Oxford

Prieur, D. (1981). Experimental studies of trophic relationships between marine bacteria and bivalve molluscs. Kieler Meeresforsch. (Sonderh.) 5: 376-383

Radziejewska, T. (1986). On the role of Mytilus edulis aggregations in enhancing meiofauna communities of the southern Baltic coast. Ophelia (Suppl. 4): 211-218

Rice, D. L. (1982). The detritus nitrogen problem: new observations and perspectives from organic geochemistry. Mar. Ecol. Prog. Ser. 9: 153-162

Robinson, J. D., Mann, K. H., Novitsky, J. A. (1982). Conversion of the particulate fraction of seaweed detritus to bacterial biomass. Limnol. Oceanogr. 27 (6): 1072-1079

Russel-Hunter, W. D. (1970). Aquatic productivity. Macmillan, New York

Simpson, W R. (1982). Particulate matter in the oceans sampling methods, concentration, size distribution and particle dynamics. Oceanogr. mar. Biol. A. Rev. 20: $119-172$

Smaal, A. C., Verhagen, J. H. G., Coosen, J., Haas, H. A. (1986). Interaction between seston quantity and quality and benthic suspension feeders in the Osterschelde, The Netherlands. Ophelia 26: 385-399

Steele, J. H., Baird, I. E. (1972). Sedimentation of organic matter in Scottish sea loch. Mem. inst. ital. Idrobiol 29: 73-88

Strickland, J. D. H. (1960). Measuring the production of marine phytoplankton. Bull. Fish. Res. Bd Can. 122: 1-172

Stuart, V., Newell, R. C., Lucas, M. I. (1982). Conversion of kelp debris and faecal material from the mussel Aulacomya ater by marine microorganisms. Mar. Ecol Prog. Ser. 7: 47-57

Stuart, V., Klumpp, D. W. (1984). Evidence for food-resource partitioning by kelp-bed filter feeders. Mar Ecol. Prog. Ser. 16: 27-37

Tenore, K. R., Goldman, J. C., Clarner, J. P. (1973). The food chain dynamics of the oyster, clam, and mussel in an aquaculture food chain. J. exp. mar. Biol, Ecol. 12: 157-165

Tenore, K. R., Dunstan, W. M. (1973a). Comparison of feeding and biodeposition of three bivalves at different food levels Mar. Biol. 21: 190-195

Tenore, K. R., Dunstan, W. M. (1973b). Comparison of roles of feeding and biodeposition of the American oyster Crassostrea virginica Gmelin, fed different species of phytoplankton. J. exp. mar Biol. Ecol. 12: 19-26

Tenore, K. R., Hansson, R. B., Donseif, B. E., Wiederhold, C. N. (1979). The effect of organic nitrogen supplement on utilization of different sources of detritus. Limnol. Oceanogr. 84: 350-355

Tenore, K. R., Rice, D. L. (1980). A review of trophic factors affecting secondary production of deposit feeders. In: Coull, B. C., Tenore, K. R. (ed.) Marine benthic dynamics. Univ. South Carolina Press, Columbia, p. 325-340

Tenore, K. R., Boyer, L. F., Cal, R. M., Corall, J., GarciaFernandez, C., Gonzalez, N., Gonzalez-Gurriaran, E., Hanson, R. B., Iglesias, J., Krom, M., Lopez-Jamar, E., 
McClain, J., Pamatmat, M. M., Perez, A., Rhoads, D. C., de Santiago, G., Tietjen, J., Westrich, J., Windom, H. L. (1982). Coastal upwelling in the Rias Bajas, NW Spain. contrasting the Rias de Arosa and the Muros. J. mar. Res. 40: 701-772

Theisen, B. F. (1968). Growth and mortality of culture mussels in the Danish Wadden Sea. Meddr Danm. Fisk.-og Havunders. N. S. 6:47-78

Tsuchiya, M. (1980). Biodeposit production by the mussel Mytilus edulis L. on rocky shores. J. exp. mar. Biol. Ecol. 47: 203-222

Tsuchiya, M., Nishihira, M. (1985). Islands of Mytilus as habitat for small intertidal animals: effect of island size on community structure. Mar. Ecol. Prog. Ser. 25: 71-81

Vahl, O. (1972). Efficiency of particle retention in Mytilus edulis L. Ophelia 10: 17-25

Vahl, O. (1980). Volume of water pumped and particulate matter deposited by the iceland scallop (Chlamys islandica) in Balsfjord, Northern Norway. In: Freeland, H. J.,
Farmer, D. M., Levings, C. D. (ed.) Fjord oceanography Plenum Publ. Corp., New York, p. 639-643

Valiela, J. (1984). Marine ecological processes. Springer-Verlag, New York

Verhoff, F. H., DePinto, J. V. (1977). Modeling and experimentation related to bacterial-mediated degradation of algae and its effect on nutrient regeneration in lakes. Devs ind. Microbiol. 18: 213-219

Verwey, J. (1952). On the ecology and distribution of cockle and mussel in the Dutch Waddensea, their role in sedimentation and the source of their food supply, with a short review of the feeding behaviour of bivalve molluscs. Archs neerl. Zool. 10: 172-239

Wildish, D. J,, Kristmanson, D. D. (1984). Importance to mussels of the Benthic boundary layer. Can. J. Fish. Aquat. Sci. 41: 1618-1625

Zeitzschel, B. (1980). Sediment-water interaction and nutrient dynamics. In: Tenore, K. R., Coull, B. C. (ed.) Marine benthic dynamics. Univ. S. Carolina Press, Columbia, p. $195-218$ 